\title{
Solvent Effects on the UV-Visible Absorption Spectra of Some New 3-Methyl-5-(Phenylamino)-4-((4-Phenylazo- Phenyl)Azo)-2-Substituted Thiophene Dyes
}

\author{
Afnan M. El-badrawy ${ }^{1}{ }^{\mathbb{D}}$, Nanees Nagy ${ }^{1}{ }^{\mathbb{D}}$, Ehab Abdel-Latif ${ }^{1, *}{ }^{\mathbb{D}}$, Ahmed A. Fadda ${ }^{1 \mathbb{D}}$ \\ 1 Department of Chemistry, Faculty of Science, Mansoura University, 35516 Mansoura, Egypt \\ * Correspondence: ehabattia00@gmx.net;
}

Scopus Author ID 6603111438

Received: 29.12.2020; Revised: 22.01.2021; Accepted: 25.01.2021; Published: 31.01.2021

\begin{abstract}
The preparation of 3-methyl-5-(phenylamino)-4-((4-phenylazo-phenyl)azo)thiophene dyes 4a-d, having different polar groups at the second position, was described through hetero-cyclization of the precursor 4-mercapto-4-(phenylamino)-3-((4-phenylazo-phenyl)azo)but-3-en-2-one (3) with various $\alpha$-chlorinated reagents. The absorption spectra of the synthesized thiophene dyes were studied in three solvents $\left(\mathrm{MeOH}, \mathrm{CHCl}_{3}\right.$, and DMF) to correlate the effect of solvent polarity as well as chemical structures on absorption in the UV-vis region. The absorption maximum $\left(\lambda_{\max }\right)$ changed from 486 to $502 \mathrm{~nm}$ in methanol, from 502 to $512 \mathrm{~nm}$ in chloroform, and from 626 to $654 \mathrm{~nm}$ in DMF. The benzoyl group's introduction in the second position of the thiophene ring brings the absorption maxima to higher values (bathochromic shift).
\end{abstract}

Keywords: 4-(phenylazo)aniline; chloroacetone; bis-azo thiophene; UV-visible absorption; solvent effect.

(c) 2021 by the authors. This article is an open-access article distributed under the terms and conditions of the Creative Commons Attribution (CC BY) license (https://creativecommons.org/licenses/by/4.0/).

\section{Introduction}

Azo dyes constitute $70 \%$ of dye chemistry, and their relative significance may increase in the future [1-11]. The widespread study of azo dyes is due to various chemical structures and application methods [12-20]. Numerous azo dyes were applied for dyeing natural fibers (cotton, silk, and wool) and synthetic fibers (polyesters, polyamides, acrylics, and viscose rayon) [21-25]. They are widely used to dye leather, plastics, paper, cosmetics, and foods $[26,27]$. Besides, some bis-azo dyes containing a conjugated group (phenol and/or nitro-phenol moiety) display green luminescence [28-31]. Several heterocyclic azo dyes were introduced on the market to generate azo disperse dyestuffs based on different heteroaromatic diazo or coupling components [32,33]. Azo dyes derived from nitrogen and/or sulfur heterocyclic ring systems were used in printing, laser technology, electronic photography, and solar energy [3439]. Thiophene-based sensitizers are attractive because of their intrinsic conjugation of electrons that promotes the charge transfer process [40]. Furthermore, thiophene compounds are excellent fluorescent materials with high photo-luminescent performance [41-44]. Heterocyclic azo dyes were recently reported as an attractive research topic for chemists [45] and dyes manufacturers [46]. Especially, thiophene-based azo dyes have gained great interest since they are used in dye-sensitized solar cells (DSSCs) and semiconducting compounds [4752]. The present paper describes the synthesis of 2-substituted-3-methyl-5-(phenylamino)-4((4-phenylazo-phenyl)azo)thiophene dyes by cyclization the precursor 2-acetyl-2-(4- 
phenylazo-phenyl)thioacetanilide with four chlorinated reagents $\left(\mathrm{CH}_{3} \mathrm{COCH}_{2} \mathrm{Cl}, \mathrm{PhCOCH}_{2} \mathrm{Cl}\right.$, $\mathrm{ClCH}_{2} \mathrm{COOEt}$ and/or $\mathrm{ClCH}_{2} \mathrm{CN}$ ).

\section{Materials and Methods}

The ultraviolet-visible absorption spectra were measured on a Shimadzu 1700 spectrophotometer in the region 200-600 $\mathrm{nm}$. The IR spectra were obtained on the Thermo Scientific Nicolet iS10 FTIR spectrometer. ${ }^{1} \mathrm{H}$ NMR spectra were measured in DMSO- $d_{6}$ as a solvent at $500 \mathrm{MHz}$ on JEOL's spectrometer. Perkin-Elmer 2400 analyzer has been used to determine the elemental analyses.

\subsection{Preparation of 4-mercapto-4-(phenylamino)-3-((4-phenylazo-phenyl)azo)but-3-en-2-one} (3).

A well-stirred solution of 4-(phenylazo)aniline (3.94 g, $0.02 \mathrm{~mol})$ in concentrated $\mathrm{HCl}$ $(6 \mathrm{~mL})$ was cooled at $0-5^{\circ} \mathrm{C}$. Then sodium nitrite solution was added $(1.40 \mathrm{~g}$ in $10 \mathrm{~mL}$ water $)$. The diazonium solution that was obtained was added drop by drop to a cold suspension of 2acetyl-3-oxo- $N$-phenyl butane thioamide (2) $(4.70 \mathrm{~g}, 0.02 \mathrm{~mol})$ and sodium acetate $(6.00 \mathrm{~g})$ in $50 \mathrm{~mL}$ ethanol. The reaction components were stirred for 2 hours at $0-5^{\circ} \mathrm{C}$. The crude bis-azo dye 3 was collected, dried, and recrystallized from ethanol.

Orange solid, yield $=63 \%$, m.p. $=134-135^{\circ} \mathrm{C} . \mathrm{IR}(\mathrm{KBr}): 3435(\mathrm{NH}), 1648(\mathrm{C}=\mathrm{O}), 1595$ $(\mathrm{C}=\mathrm{N}), 1525 \mathrm{~cm}^{-1}(\mathrm{~N}=\mathrm{N}) .{ }^{1} \mathrm{H}$ NMR: 2.19 (s, 1H, SH), 2.48 (s, 3H, CH3), 7.44-8.10 (m, 14H, Ar-H), 12.16 ppm (s, 1H, NH). Anal. Calcd. for $\mathrm{C}_{22} \mathrm{H}_{19} \mathrm{~N}_{5} \mathrm{OS}$ (401.13); C, 65.82; H, 4.77; N, 17.44. Found; C, 65.88; H, 4.74; N, 17.49\%.

2.2. Preparation of 3-methyl-5-(phenylamino)-4-((4-phenylazo-phenyl)azo)thiophene dyes 4a$d$.

To a suspension of thiol derivatives $3(0.40 \mathrm{~g}, 0.001 \mathrm{~mol})$ in sodium ethoxide solution (prepared from $0.05 \mathrm{~g} \mathrm{Na}$ metal and $20 \mathrm{~mL}$ dry ethanol), $0.001 \mathrm{~mol}$ of each appropriate chlorinated reagent (namely; $\mathrm{CH}_{3} \mathrm{COCH}_{2} \mathrm{Cl}, \mathrm{PhCOCH}_{2} \mathrm{Cl}, \mathrm{ClCH}_{2} \mathrm{COOEt}$ and/or $\mathrm{ClCH}_{2} \mathrm{CN}$ ) was added. The reaction components were refluxed for 2 hours and then cooled to $30^{\circ} \mathrm{C}$. The solid that formed upon the addition of ice-cold water and neutralized by dilute $\mathrm{HCl}$ was collected and washed with water. The solid obtained in each case was recrystallized from ethanol to give the targeted thiophene derivatives $4 \mathrm{a}-\mathrm{d}$.

2.2.1. 2-Acetyl-3-methyl-5-(phenylamino)-4-((4-phenylazo-phenyl)azo)thiophene (4a).

Red solid, yield $=82 \%$, m.p. $=215-217^{\circ} \mathrm{C} . \mathrm{IR}: 3386(\mathrm{~N}-\mathrm{H}), 1637 \mathrm{~cm}^{-1}(\mathrm{C}=\mathrm{O}) .{ }^{1} \mathrm{H}$ NMR: 2.56 (s, 3H, $\mathrm{CH}_{3}$ ), 2.65 (s, 3H, $\mathrm{CH}_{3}$ ), 7.33-8.05 (m, 14H, Ar-H), 14.29 ppm (s, 1H, NH). Anal. Calcd. for $\mathrm{C}_{25} \mathrm{H}_{21} \mathrm{~N}_{5} \mathrm{OS}$ (439.15): C, 68.32; H, 4.82; N, 15.93\%. Found; C, 68.20; H, 4.86; N, $15.98 \%$.

2.2.2. 2-Benzoyl-3-methyl-5-(phenylamino)-4-((4-phenylazo-phenyl)azo)thiophene (4b).

Reddish brown solid, yield $=73 \%$, m.p. $=183-184^{\circ} \mathrm{C}$. IR: $3443(\mathrm{~N}-\mathrm{H}), 1622 \mathrm{~cm}^{-1}$ $(\mathrm{C}=\mathrm{O}) .{ }^{1} \mathrm{H}$ NMR: 2.22 (s, 3H, CH3), 7.28-7.99 (m, 19H, Ar-H), 14.18 ppm (s, 1H, NH). Anal. Calcd. for $\mathrm{C}_{30} \mathrm{H}_{23} \mathrm{~N}_{5} \mathrm{OS}$ (501.16): C, 71.83; H, 4.62; N, 13.96\%. Found; C, 71.91; H, 4.60; N, $13.88 \%$. 
2.2.3. 2-Ethoxycarbonyl-3-methyl-5-(phenylamino)-4-((4-phenylazo-phenyl)azo)thiophene $(4 c)$.

Dark red solid, yield $=75 \%$, m.p. $=150-151^{\circ} \mathrm{C} . \mathrm{IR}: 3423(\mathrm{~N}-\mathrm{H}), 1704 \mathrm{~cm}^{-1}(\mathrm{C}=\mathrm{O}$ ester $)$. ${ }^{1} \mathrm{H}$ NMR: 1.23 (t, $\left.J=7.20 \mathrm{~Hz}, 3 \mathrm{H}, \mathrm{CH}_{3}\right), 2.21\left(\mathrm{~s}, 3 \mathrm{H}, \mathrm{CH}_{3}\right), 4.33$ (q, $J=7.20 \mathrm{~Hz}, 2 \mathrm{H}, \mathrm{CH}_{2}$ ), 7.03-7.96 (m, 14H, Ar-H), 14.44 ppm (s, 1H, NH). Anal. Calcd. for $\mathrm{C}_{26} \mathrm{H}_{23} \mathrm{~N}_{5} \mathrm{O}_{2} \mathrm{~S}$ (469.16); C, 66.51; H, 4.94; N, 14.91\%. Found; C, 66.66; H, 4.86; N, $14.82 \%$.

2.2.4. 2-Cyano-3-methyl-5-(phenylamino)-4-((4-phenylazo-phenyl)azo)thiophene (4d).

Dark red solid, yield $=88 \%$, m.p. $=209-211^{\circ} \mathrm{C}$. IR: $3394(\mathrm{~N}-\mathrm{H}), 2203 \mathrm{~cm}^{-1}(\mathrm{C} \equiv \mathrm{N}) .{ }^{1} \mathrm{H}$ NMR: 2.44 (s, 3H, CH3), 7.36-8.04 (m, 14H, Ar-H), 14.27 ppm (s, 1H, NH). Anal. Calcd. for $\mathrm{C}_{24} \mathrm{H}_{18} \mathrm{~N}_{6} \mathrm{~S}$ (422.13): C, 68.23; H, 4.29; N, 19.89\%. Found; C, 68.12; H, 4.27; N, $19.87 \%$.

\section{Results and Discussion}

\subsection{Synthesis and characterization of bis-azo thiophene dyes $4 a-d$.}

4-(Phenylazo)aniline (1) has been easily diazotized by the action of nitrous acid (sodium nitrite and $\mathrm{HCl}$ ) at $0-5^{\circ} \mathrm{C}$ to form the corresponding diazonium intermediate (A). In situ coupling of the freshly obtained diazonium salt (A) with 2-acetyl-3-oxo- $N$-phenyl butane thioamide (2) to furnish the coupling product, 4-mercapto-4-(phenylamino)-3-((4-phenylazophenyl)azo)but-3-en-2-one (3) (Scheme 1). The coupling process was performed in ethanol and sodium acetate and accompanied by loss of acetyl group (Japp-Klingemann reaction).

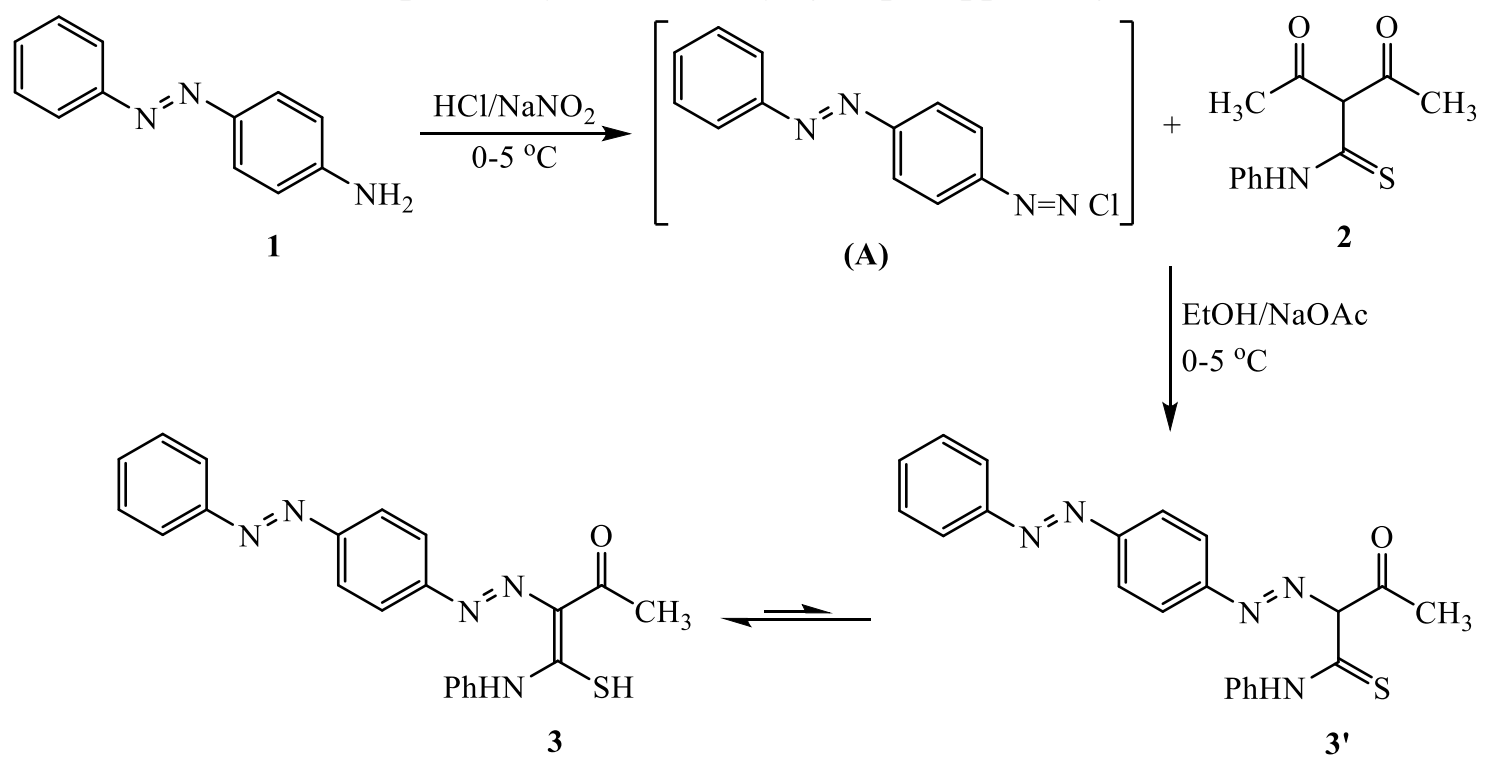

Scheme 1. Formation of the thiocarbamoyl compound 3.

The reaction of thiol compound 3 with various chlorinated reagents (namely; chloroacetone, phenacyl chloride, ethyl chloroacetate, and chloroacetonitrile) was achieved in boiling ethyl alcohol and sodium ethoxide to give the corresponding 3-methyl-5(phenylamino)-4-((4-phenylazo-phenyl)azo)thiophene dyes 4a-d (Scheme 2). The suggested mechanism for preparing these bis-azo thiophene dyes involves initial alkylation of thiol compound 3 with each alpha-chlorinated reagent to form the thioether intermediate of the type B followed by in situ cyclization that proceeds by the elimination of water molecule from the methylene and carbonyl groups. The structures of bis-azo thiophene dyes $4 \mathrm{a}-\mathrm{d}$ were established by their elemental and spectral analyses. The IR spectra of the synthesized bis-azo thiophene 
dyes $4 \mathrm{a}-\mathrm{d}$ showed the absorption of N-H function in the range $3443-3386 \mathrm{~cm}^{-1}$. The absorption of the carbonyl group of 2-benzoylthiophene dye $4 \mathrm{~b}$ was identified at lower wavenumber (1622 $\mathrm{cm}^{-1}$ ) due to high conjugation with benzene thiophene rings. The carbonyl group of 2-acetyl thiophene dye 4a was observed at a slightly higher frequency $\left(1637 \mathrm{~cm}^{-1}\right)$ because of conjugation with the thiophene ring. The characteristic absorption of the carbonyl group of 2ethoxy-carbonyl thiophene dye $4 \mathrm{c}$ was observed at a higher wavenumber $\left(1704 \mathrm{~cm}^{-1}\right)$. The ${ }^{1} \mathrm{H}$ NMR spectrum of bis-azo thiophene dye 4a (as an example) displayed two singlet signals at $\delta$ 2.56 and $2.65 \mathrm{ppm}$ for the methyl protons group (thiophene- $\mathrm{CH}_{3}$ and $\mathrm{COCH}_{3}$, respectively). The aromatic protons resonate as multiplet in the region $\delta 7.33-8.05 \mathrm{ppm}$. The singlet at $\delta 14.29$ ppm referred to the proton of the $\mathrm{N}-\mathrm{H}$ function.

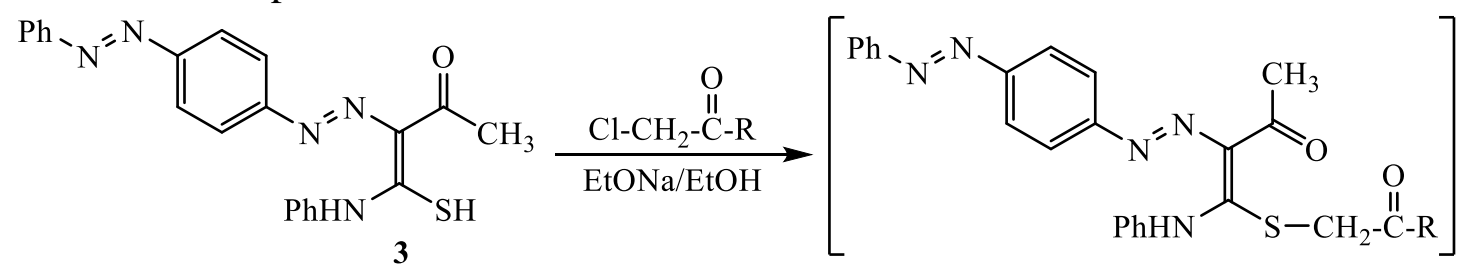<smiles>Cc1c(C#N)sc(Nc2ccccc2)c1N=Nc1ccc(N=Nc2ccccc2)cc1</smiles>

4d
(B)

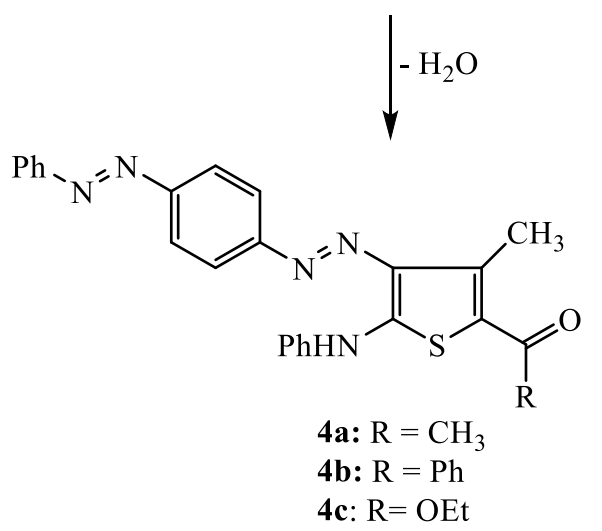

Scheme 2. Formation of bis-azo thiophene dyes $4 \mathrm{a}-\mathrm{d}$.

\section{2. $U V$-visible spectra of thiophene dyes 4a-d.}

The absorption maxima (UV-visible spectra) of 3-methyl-5-(phenylamino)-4-((4phenylazo-phenyl)azo)thiophene dyes 4a-d was explored using three types of solvents $(\mathrm{MeOH}$, $\mathrm{CHCl}_{3}$, and DMF) with different polarities. In general, different colors of the synthesized bisazo thiophene dyes result from either alternation of the substituent that occupies position number two at the thiophene ring. The color of the synthesized bis-azo thiophene dyes changed from orange to reddish-brown. The absorption spectra of dye solution were examined to estimate the color. The wavelength at maximum absorption of the synthesized 3-methyl-5(phenylamino)-4-((4-phenylazo-phenyl)azo)thiophene dyes 4a-d were measured in three solvents with diverse polarity (dimethylformamide, chloroform, and methanol). The absorption maximum $\left(\lambda_{\max }\right)$ of the constructed bis-azo thiophene dyes in DMF (table 1) changed from 626 to $654 \mathrm{~nm}$. They displayed a tight range (500-512 $\mathrm{nm}$ ) in chloroform and (478-502) $\mathrm{nm}$ in methanol. Among the four bis-azo thiophene dyes $4 a-d$ under investigation, the relationship between the change of absorption maxima, and polarities of the solvents and substituents, the following can be summarized:

(a) In DMF, the absorption $\lambda_{\max }$ values were higher than their conforming values in chloroform and methanol for the four bis-azo thiophene dyes $4 \mathrm{a}, 4 \mathrm{~b}, 4 \mathrm{c}$, and 4d. 
(b) DMF created more bathochromic shifts than chloroform and methanol. The highest observed $\lambda_{\max }$ value was $654 \mathrm{~nm}$ in DMF for the bis-azo thiophene dye $4 \mathrm{~b}$ that substituted with benzoyl group at the second position of thiophene ring.

(c) In all solvents, the benzoyl group's introduction at the second position of the thiophene ring affects shifting the absorption maxima to higher values (bathochromic shift).

(d) In all solvents, the cyano group's introduction at the second position of the thiophene ring affects shifting the absorption maxima to lower values (hypsochromic shift).

(e) The bathochromic effect of the substituent at the second position of thiophene follows the order: $\mathrm{COPh}\left(4 \mathrm{~b}: \lambda_{\max }=654\right)>\mathrm{COMe}\left(4 \mathrm{~b}: \lambda_{\max }=646\right)>\operatorname{COOEt}\left(4 \mathrm{c}: \lambda_{\max }=642\right)>\mathrm{CN}$ $\left(4 \mathrm{~d}: \lambda_{\max }=626\right)$.

(f) In chloroform, the absorption maximum $\left(\lambda_{\max }\right)$ of the four bis-azo thiophene dyes $4 \mathrm{a}, 4 \mathrm{~b}$, $4 \mathrm{c}$, and $4 \mathrm{~d}$ occupy a compact range of wavelengths values $(500-512 \mathrm{~nm})$.

Table 1. UV-visible absorption wavelength $\left(\lambda_{\max }, \mathrm{nm}\right)$ of bis-azo thiophene dyes $4 \mathrm{a}-\mathrm{d}$ in $\mathrm{DMF}, \mathrm{CHCl}_{3}$, and

\begin{tabular}{c|c|c|c}
\multicolumn{4}{|c}{ MeOH. } \\
Dye No. & DMF & CHCl $_{3}$ & MeOH \\
\hline $\mathbf{3}$ & $264,432,---$ & 264,414 & 264,402 \\
\hline $\mathbf{4 a}$ & $264,510,646$ & 662,508, & 258,500 \\
\hline $\mathbf{4 b}$ & $266,510,654$ & 272,512 & 262,502 \\
\hline $\mathbf{4 c}$ & $266,502,642$ & 258,500 & 262,478 \\
\hline $\mathbf{4 d}$ & $264,502,626$ & 262,502 & 258,486
\end{tabular}
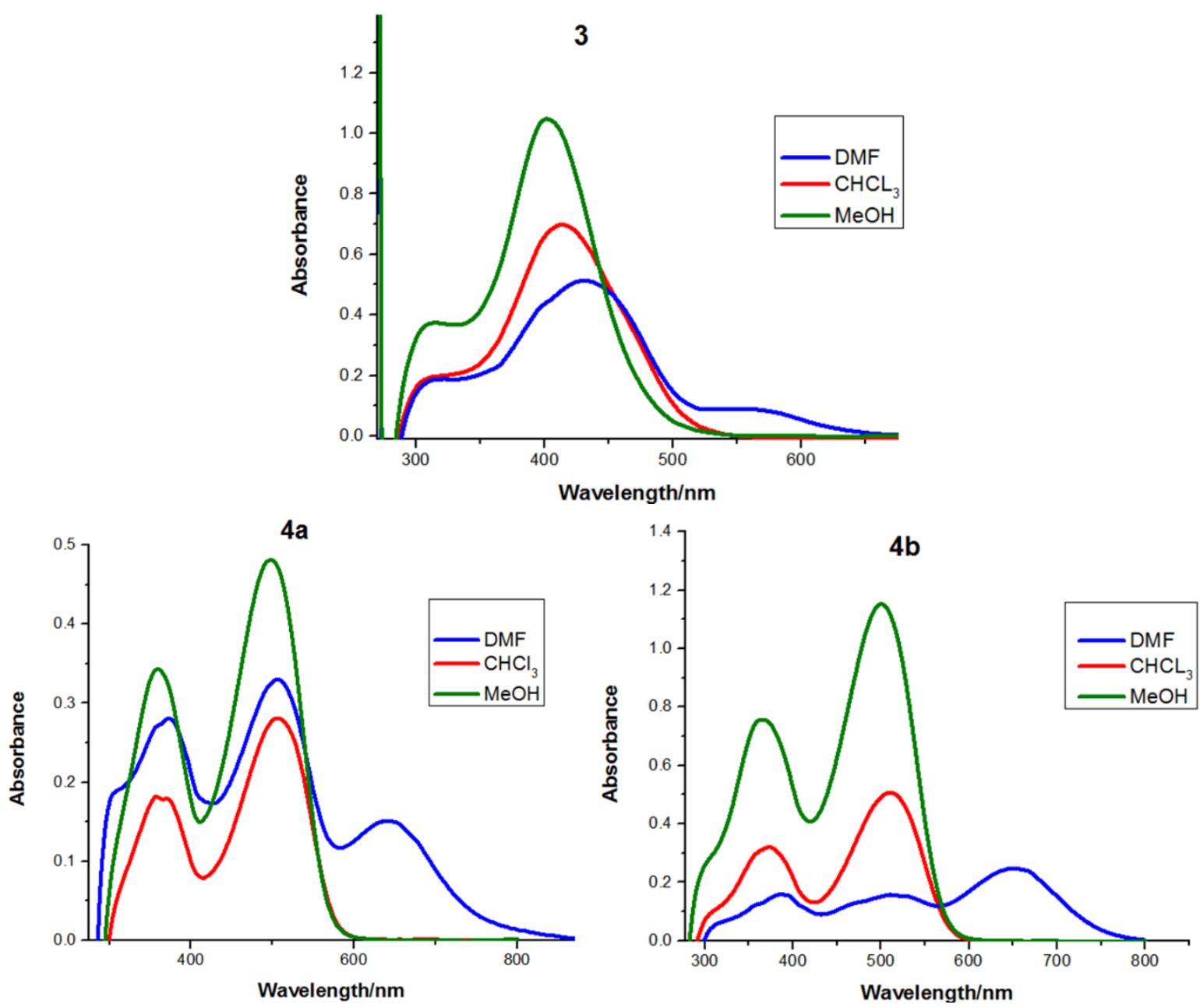

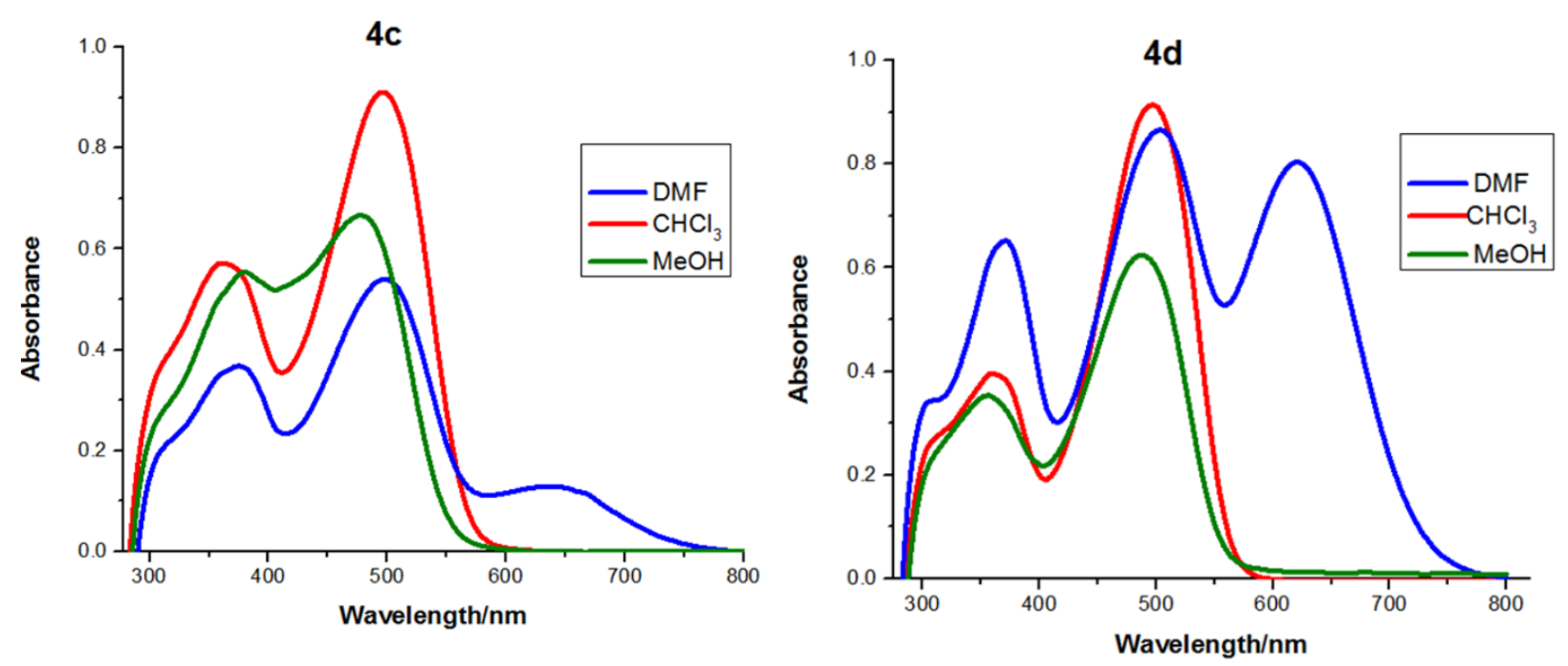

Figure 1. UV-visible spectra of dyes 3 and 4a-d in $\mathrm{DMF}, \mathrm{CHCl}_{3}$ and $\mathrm{MeOH}$.

\section{Conclusions}

In conclusion, a series of four 3-methyl-5-(phenylamino)-4-((4-phenylazophenyl)azo)-2-substitutedthiophene dyes 4a-d was succesfully prepared and their absorption spectra were studied in $\mathrm{MeOH}, \mathrm{CHCl}_{3}$, and DMF. The absorption maximum $\left(\lambda_{\max }\right)$ changed from 486 to $502 \mathrm{~nm}$ in methanol, from 502 to $512 \mathrm{~nm}$ in chloroform, and from 626 to $654 \mathrm{~nm}$ in DMF. The substitutent at the second position of the thiophene ring clearly affecting the absorption maxima to follow this order in DMF: COPh $\left(4 \mathrm{~b}: \lambda_{\max }=654\right)>\mathrm{COMe}\left(4 \mathrm{~b}: \lambda_{\max }=\right.$ $646)>\operatorname{COOEt}\left(4 \mathrm{c}: \lambda_{\max }=642\right)>\mathrm{CN}\left(4 \mathrm{~d}: \lambda_{\max }=626\right)$.

\section{Funding}

This research received no external funding.

\section{Acknowledgments}

This research has no acknowledgment.

\section{Conflicts of Interest}

The authors declare no conflict of interest.

\section{References}

1. Benkhaya, S.; M'Rabet, S.; El Harfi, A. Classifications, properties, recent synthesis and applications of azo dyes. Heliyon 2020, 6, e03271, https://doi.org/10.1016/j.heliyon.2020.e03271.

2. Srinivasan, S.; Sadasivam, S.K. Biodegradation of textile azo dyes by textile effluent non-adapted and adapted Aeromonas hydrophila. Environ. Res. 2020, 110643, https://doi.org/10.1016/j.envres.2020.110643.

3. Rashidnejad, H.; Ramezanitaghartapeh, M.; Pesyan, N.N.; Mahon, P.J.; Raposo, M.Manuela M.; Coelho, P.J.; Lup, A.N.K.; Soltani, A. A comprehensive spectroscopic, solvatochromic and photochemical analysis of 5hydroxyquinoline and 8-hydroxyquinoline mono-azo dyes. J. Mol. Struct. 2021, 1223, 129323, https://doi.org/10.1016/j.molstruc.2020.129323.

4. Alsoghier, H.M.; Abdellah, M.; Rageh, H.M.; Salman, H.M.A.; Selim, M.A.; Santos, M.A.; Ibrahim, S.A. NMR spectroscopic investigation of benzothiazolylacetonitrile azo dyes: CR7 substitution effect and semiempirical study. Results in Chemistry 2021, 3, 100088, https://doi.org/10.1016/j.rechem.2020.100088.

5. Prashantha, A.G.; Shoukat Ali, R.A.; Keshavayya, J. Synthesis, Spectral characterization, DFT studies and antimicrobial activities of Amino-methylbenzoic acid based Azo Dyes. Inorg. Chem. Commun. 2020, 108392, https://doi.org/10.1016/j.inoche.2020.108392. 
6. Chen, J.; Hu, H.; Yang, J.; Xue, H.; Tian, Y.; Fan, K.; Zeng, Z.; Yang, J.; Wang, R.; Liu, Y. Removal behaviors and mechanisms for series of azo dye wastewater by novel nano constructed macro-architectures material. Bioresour. Technol. 2021, 322, 124556, https://doi.org/10.1016/j.biortech.2020.124556.

7. Selvaraj, V.; Swarna Karthika, T.; Mansiya, C.; Alagar, M. An over review on recently developed techniques, mechanisms and intermediate involved in the advanced azo dye degradation for industrial applications. J. Mol. Struct. 2021, 1224, 129195, https://doi.org/10.1016/j.molstruc.2020.129195.

8. Omar, A.Z.; Mahmoud, M.N.; El-Sadany, S.K.; Hamed, E.A.; El-atawy, M.A. A combined experimental and DFT investigation of mono azo thiobarbituric acid based chalcone disperse dyes. Dyes and Pigments 2021, 185, 108887, https://doi.org/10.1016/j.dyepig.2020.108887.

9. Gester, R.; Torres, A.; Bistafa, C.; Araújo, R.S.; da Silva, T.A.; Manzoni, V. Theoretical study of a recently synthesized azo dyes useful for OLEDs. Mater. Lett. 2020, 280, 128535, https://doi.org/10.1016/j.matlet.2020.128535.

10. Ben Mohamed-Smati, S.; Faraj, F.L.; Becheker, I.; Berredjem, H.; Le Bideau, F.; Hamdi, M.; Dumas, F.; Rachedi, Y. Synthesis, characterization and antimicrobial activity of some new azo dyes derived from 4hydroxy-6-methyl-2H-pyran-2-one and its dihydro derivative. Dyes and Pigments 2020, 109073, https://doi.org/10.1016/j.dyepig.2020.109073.

11. Weldegebrieal, G.K. Synthesis method, antibacterial and photocatalytic activity of ZnO nanoparticles for azo dyes in wastewater treatment: A review. Inorg. Chem. Commun. 2020, 120, 108140, https://doi.org/10.1016/j.inoche.2020.108140.

12. Berradi, M.; Hsissou, R.; Khudhair, M.; Assouag, M.; Cherkaoui, O.; El Bachiri, A.; El Harfi, A. Textile finishing dyes and their impact on aquatic environs. Heliyon 2019, 5, e02711, https://doi.org/10.1016/j.heliyon.2019.e02711.

13. Bártová, K.; Císařová, I.; Lyčka, A.; Dračínský, M. Tautomerism of azo dyes in the solid state studied by $15 \mathrm{~N}$, 14N, 13C and 1H NMR spectroscopy, X-ray diffraction and quantum-chemical calculations. Dyes and Pigments 2020, 178, 108342, https://doi.org/10.1016/j.dyepig.2020.108342.

14. Maliyappa, M.R.; Keshavayya, J.; Mallikarjuna, N.M.; Pushpavathi, I. Novel substituted aniline based heterocyclic dispersed azo dyes coupling with 5-methyl-2-(6-methyl-1, 3-benzothiazol-2-yl)-2, 4-dihydro-3Hpyrazol-3-one: Synthesis, structural, computational and biological studies. J. Mol. Struct. 2020, 1205, 127576, https://doi.org/10.1016/j.molstruc.2019.127576.

15. Ravi, B.N.; J, K.; M, M.N.; Kumar, V.; Kandgal, S. Synthesis, characterization and pharmacological evaluation of 2-aminothiazole incorporated azo dyes. J. Mol. Struct. 2020, 1204, 127493, https://doi.org/10.1016/j.molstruc.2019.127493.

16. Qiu, J.; Tang, B.; Ju, B.; Zhang, S.; Jin, X. Clean synthesis of disperse azo dyes based on peculiar stable 2,6dibromo-4-nitrophenyl diazonium sulfate. Dyes and Pigments 2020, 173, 107920, https://doi.org/10.1016/j.dyepig.2019.107920.

17. Kiayi, Z.; Lotfabad, T.B.; Heidarinasab, A.; Shahcheraghi, F. Microbial degradation of azo dye carmoisine in aqueous medium using Saccharomyces cerevisiae ATCC 9763. J. Hazard. Mater. 2019, 373, 608-619, https://doi.org/10.1016/j.jhazmat.2019.03.111.

18. Maliyappa, M.R.; Keshavayya, J.; Mallikarjuna, N.M.; Murali Krishna, P.; Shivakumara, N.; Sandeep, T.; Sailaja, K.; Nazrulla, M.A. Synthesis, characterization, pharmacological and computational studies of 4, 5, 6, 7tetrahydro-1, 3-benzothiazole incorporated azo dyes. J. Mol. Struct. 2019, 1179, 630-641, https://doi.org/10.1016/j.molstruc.2018.11.041.

19. Szadkowski, B.; Marzec, A.; Rogowski, J.; Maniukiewicz, W.; Zaborski, M. Insight into the formation mechanism of azo dye-based hybrid colorant: Physico-chemical properties and potential applications. Dyes and Pigments 2019, 167, 236-244, https://doi.org/10.1016/j.dyepig.2019.04.022.

20. Vinodkumar; Keshavayya, J. Synthesis, structural investigations and in vitro biological evaluation of N, Ndimethyl aniline derivatives based azo dyes as potential pharmacological agents. J. Mol. Struct. 2019, 1186, 404-412, https://doi.org/10.1016/j.molstruc.2019.03.042.

21. Al-Azmi, A.; John, E. Synthesis of 4-arylazo-2-(N-pyrazolylcarboxamido)thiophene disperse dyes for dyeing of polyester and their antibacterial evaluation. Textile Research Journal 2020, 90, 2795-2805, https://doi.org/10.1177/0040517520931476.

22. Ghanavatkar, C.W.; Mishra, V.R.; Sekar, N. Benzothiazole-pyridone and benzothiazole-pyrazole clubbed emissive azo dyes and dyeing application on polyester fabric: UPF, biological, photophysical and fastness properties with correlative computational assessments. Spectrochimica Acta Part A: Molecular and Biomolecular Spectroscopy 2020, 230, 118064, https://doi.org/10.1016/j.saa.2020.118064. 
23. Siddiqua, U.H.; Irfan, M.; Ali, S.; Sahar, A.; Khalid, M.; Mahr, M.S.; Iqbal, J. Computational and experimental study of heterofunctional azo reactive dyes synthesized for cellulosic fabric. J. Mol. Struct. 2020, 1221, 128753, https://doi.org/10.1016/j.molstruc.2020.128753.

24. Ayare, N.N.; Ramugade, S.H.; Sekar, N. Photostable coumarin containing azo dyes with multifunctional property. Dyes and Pigments 2019, 163, 692-699, https://doi.org/10.1016/j.dyepig.2018.12.050.

25. Kadhim, Z.Y.; Seewan, A.N.; Abd, M.T.; Saud, H.R. Synthesis, Characterization, Antibacterial Screening and application on the wool fabric of new Bis-azo Compounds derived from 4, 4'-Diaminodiphenylmethane. International Journal of Pharmaceutical Research 2020, 12, 402-407, https://doi.org/10.31838/ijpr/2020.12.03.062.

26. Dhungana, B.; Peng, H.; Kutarna, S.; Umbuzeiro, G.; Shrestha, S.; Liu, J.; Jones, P.D.; Subedi, B.; Giesy, J.P.; Cobb, G.P. Abundances and concentrations of brominated azo dyes detected in indoor dust. Environ. Pollut. 2019, 252, 784-793, https://doi.org/10.1016/j.envpol.2019.05.153.

27. Zhi-Gang, Y.; Chun-Xia, Z.; De-Feng, Z.; Freeman, H.S.; Pei-Tong, C.; Jie, H. Monoazo dyes based on 5,10dihydrophenophosphazine, Part 2: Azo acid dyes. Dyes and Pigments 2009, 81, 137-143, https://doi.org/10.1016/j.dyepig.2008.09.021.

28. Özdemir, Ö. Synthesis of new luminescent bis-azo-linkage Schiff bases containing amino-phenol and its derivative. Part I: Studying of their tautomeric, acidochromic, thermochromic, ionochromic, and photolüminesence properties. J. Photochem. Photobiol. A: Chem. 2019, 380, 111868, https://doi.org/10.1016/j.jphotochem.2019.111868.

29. Satapathy, A.K.; Behera, S.K.; Yadav, A.; Mahour, L.N.; Yelamaggad, C.V.; Sandhya, K.L.; Sahoo, B. Tuning the fluorescence behavior of liquid crystal molecules containing Schiff-base: Effect of solvent polarity. J. Lumin. 2019, 210, 371-375, https://doi.org/10.1016/j.jlumin.2019.02.056.

30. Özdemir, Ö. Synthesis and characterization of a new diimine Schiff base and its $\mathrm{Cu} 2+$ and Fe3+ complexes: Investigation of their photoluminescence, conductance, spectrophotometric and sensor behaviors. J. Mol. Struct. 2019, 1179, 376-389, https://doi.org/10.1016/j.molstruc.2018.11.023.

31. Özdemir, Ö. Synthesis of novel azo linkage-based Schiff bases including anthranilic acid and hexanoic acid moieties: investigation of azo-hydrazone and phenol-keto tautomerism, solvatochromism, and ionochromism. Turkish Journal of Chemistry 2019, 43, 266-285, https://doi.org/10.3906/kim-1807-24.

32. Towns, A.D. Developments in azo disperse dyes derived from heterocyclic diazo components. Dyes and Pigments 1999, 42, 3-28, https://doi.org/10.1016/S0143-7208(99)00005-4.

33. Schwander, H.R. Heterocyclic azo coupling components. Dyes and Pigments 1982, 3, 133-160, https://doi.org/10.1016/0143-7208(82)80018-1.

34. Ušćumlić, G.S.; Mijin, D.Z.; Valentić, N.V.; Vajs, V.V.; Sušić, B.M. Substituent and solvent effects on the UV/Vis absorption spectra of 5-(4-substituted arylazo)-6-hydroxy-4-methyl-3-cyano-2-pyridones. Chem. Phys. Lett. 2004, 397, 148-153, https://doi.org/10.1016/j.cplett.2004.07.057.

35. Ayare, N.N.; Sharma, S.; Sonigara, K.K.; Prasad, J.; Soni, S.S.; Sekar, N. Synthesis and computational study of coumarin thiophene-based D- $\pi$-A azo bridge colorants for DSSC and NLOphoric application. J. Photochem. Photobiol. A: Chem. 2020, 394, 112466, https://doi.org/10.1016/j.jphotochem.2020.112466.

36. Bonomo, M.; Carella, A.; Borbone, F.; Rosato, L.; Dini, D.; Gontrani, L. New pyran-based molecules as both n- and p-type sensitizers in semi-transparent Dye Sensitized Solar Cells. Dyes and Pigments 2020, 175, 108140, https://doi.org/10.1016/j.dyepig.2019.108140.

37. Raikwar, M.M.; Sonigara, K.K.; Patil, D.S.; Machhi, H.; Soni, S.S.; Sekar, N. Biphenyl-Amine-Based D- $\pi$-A'$\pi$-A Sensitizers for DSSCs: Comparative Photo-Conversion Efficiency in Iodide/triiodide and Cobalt-Based Redox Electrolyte and DFT Study. ChemistrySelect 2019, 4, 7371-7379, https://doi.org/10.1002/slct.201901247.

38. Miu, L.; Yan, S.; Yao, H.; Chen, Q.; Zhang, J.; Wang, Z.; Cai, P.; Hu, T.; Ding, S.; Chen, J.; Liang, M.; Yang, $\mathrm{S}$. Insight into the positional effect of bulky rigid substituents in organic sensitizers on the performance of dyesensitized solar cells. Dyes and Pigments 2019, 168, 1-11, https://doi.org/10.1016/j.dyepig.2019.04.048.

39. Derkowska-Zielinska, B.; Gondek, E.; Pokladko-Kowar, M.; Kaczmarek-Kedziera, A.; Kysil, A.; Lakshminarayana, G.; Krupka, O. Photovoltaic cells with various azo dyes as components of the active layer. Solar Energy 2020, 203, 19-24, https://doi.org/10.1016/j.solener.2020.04.022.

40. Xu, Q.; Li, Z.; Liu, N.; Jia, J.; Yang, J.; Song, Y. Third order nonlinear optical properties and transient dynamics of thiophene-contained pyrene derivatives: Effect of peripheral substituent group. Optics \& Laser Technology 2019, 109, 666-670, https://doi.org/10.1016/j.optlastec.2018.08.048. 
41. Davanagere, H.; Arasalike, J.; Quah, C.K.; Kwong, H.C.; Patil, P.S. Investigation of structural, physical, linear, and nonlinear optical properties of two novel thiophene centred D- $\pi$-A type push-pull organic derivatives for nonlinear optical applications. J. Mol. Struct. 2020, 1220, 128763 , https://doi.org/10.1016/j.molstruc.2020.128763.

42. Haleshappa, D.; Jayarama, A.; Quah, C.K.; Kwong, H.C. A novel bromo-substituted thiophene based centrosymmetric crystals: Thermal, mechanical, and third order NLO properties for the optical limiting applications. Physica B: Condensed Matter 2020, 585, 412083, https://doi.org/10.1016/j.physb.2020.412083.

43. Davanagere, H.; A, J.; Patil, P.S.G.; Maidur, S.R.; Quah, C.K.; Kwong, H.C. The structural and third-order nonlinear optical studies of a novel nitro group-substituted chalcone derivative for nonlinear optical applications. Appl. Phys. A 2019, 125, 309, https://doi.org/10.1007/s00339-019-2616-7.

44. Raposo, M.M.M.; Sousa, A.M.R.C.; Fonseca, A.M.C.; Kirsch, G. Thienylpyrrole azo dyes: synthesis, solvatochromic and electrochemical properties. Tetrahedron 2005, 61, 8249-8256, https://doi.org/10.1016/j.tet.2005.06.039.

45. Takagi, K.; Mizuno, A.; Iwamoto, H.; Kawashima, S.; Nishida, S.; Hashikawa, T.; Nozoe, T. Syntheses and absorption spectra of new azo dyes containing an azulene ring. Dyes and Pigments 1994, 26, 51-60, https://doi.org/10.1016/0143-7208(94)80029-4.

46. ElKholy, Y.M.; Abd El-Hafiz, S.A. Polyfunctionally Pyrazole Azo Dyes. Pigment \& resin technology 1994, https://doi.org/10.1108/eb043113.

47. Mishra, A.; Ma, C.-Q.; Bäuerle, P. Functional Oligothiophenes: Molecular Design for Multidimensional Nanoarchitectures and Their Applications. Chem. Rev. 2009, 109, 1141-1276, https://doi.org/10.1021/cr8004229.

48. Gather, M.C.; Köhnen, A.; Meerholz, K. White Organic Light-Emitting Diodes. Adv. Mater. 2011, 23, 233-248, https://doi.org/10.1002/adma.201002636.

49. Radwan, A.S.; Makhlouf, M.M.; Abdel-Latif, E. Azothiophene dyes nanotubes structure based thin films: Synthesis, structural and optical characterization toward application in dye-sensitized solar cells. Dyes and Pigments 2016, 134, 516-525, https://doi.org/10.1016/j.dyepig.2016.07.043.

50. Nazim, M.; Ameen, S.; Shaheer Akhtar, M.; Shin, H.-S. D- $\pi$-A- $\pi$-D type thiazolo[5,4-d]thiazole-core organic chromophore and graphene modified PEDOT:PSS buffer layer for efficient bulk heterojunction organic solar cells. Solar Energy 2018, 171, 366-373, https://doi.org/10.1016/j.solener.2018.06.087.

51. Mahmood, A.; Hu, J.; Tang, A.; Chen, F.; Wang, X.; Zhou, E. A novel thiazole based acceptor for fullerenefree organic solar cells. Dyes and Pigments 2018, 149, 470-474, https://doi.org/10.1016/j.dyepig.2017.10.037.

52. Etesami, H.; Mansouri, M.; Habibi, A.; Jahantigh, F. S7ynthesis and investigation of double alternating azo group in novel para-azo dyes containing nitro anchoring group for solar cell application. J. Mol. Struct. 2020, 1203, 127432, https://doi.org/10.1016/j.molstruc.2019.127432. 